\title{
IPTEK BAGI MASYARAKAT (IbM) PEMANFAATAN TEKNOLOGI TEPAT GUNA (TTG) PADA KELOMPOK MASYARAKAT PEMBUAT LAKSO DI KABUPATEN BANGKA
}

\author{
Zulfan Yus Andi ${ }^{1)}$, Yulianto ${ }^{2)}$ \\ 1\& 2) Jurusan Teknik Mesin - Politeknik Manufaktur Negeri Bangka Belitung \\ Kawasan Industri Air Kantung, Sungailiat-Bangka, 33211 \\ Tel: 0717-93586, Fax: 0717-93585, zulfan.pkp@gmail.com
}

\begin{abstract}
Lakso is one of product's traditional that made from rice flour served with coconut milk, than mixed of fish meat. Lakso always provided available in stores, events, hotels. Stage of make it from preparation of materials, mixing, molding, make kuah lakso, and ready for eating. Lakso is selling at a price of Rp.3.000 sd. Rp. 5.000 per portion and sell for drying lakso at Rp. 80,000/kg. Objectives of IbM, to improve quality and production capacity, so be able to improve at partner business management. From survey in 5 month ago, production in lakso has not been met and can not be enough for 75-80\% wet's lakso and 1\% for dry's lakso per month. Issues on partners, there are the production equipment, moulding of lakso and drying (heating from Sun). Other issues concerning the management of lakso provision, or sales. The achievements produced, the cooperation of UKM's Pak Umar with Polmanbabel, implementation for Polmanbabel's Tri Dharma that supply machine's drying for capacity at 4 - $5 \mathrm{~kg}$ (rotary rak's tray system, and aluminum material), research and Community Service by Lecturers and students. The results of activities are understanding, operation and maintenance of production in machine's provided. the achievement of percentage for drying lakso until $80 \%$ and lakso able to survive up to 3 months. Lakso's dry is able to eat by steaming process.
\end{abstract}

Keywords: lakso, Dryer, Production, Business Management.

Lakso adalah salah satu sajian tradisional yang terbuat dari tepung beras yang disajikan dengan kuah santan dengan campuran suwiran daging ikan. Lakso banyak tersedia di warung, acaraacara, hotel. Pembuatannya mulai dari persiapan bahan, pengadonan, pencetakan, pembuatan kuah, siap saji. Lakso ini jual dengan harga Rp.3.000 sd. Rp. 5.000 per porsi dan lakso kering dijual dengan harga $\mathrm{Rp} .80 .000 / \mathrm{kg}$.

Tujuan Iptek Bagi Masyarakat (IbM), untuk meningkatkan kualitas dan kapasitas produksi serta memperbaiki pengelolaan manajemen usaha mitra. Dari survey 5 bulan trakhir, masih belum terpenuhi dan tidak dapat mencukupi sekitar 75-80 \% untuk lakso basah dan 1 \% untuk lakso kering perbulan. Permasalahan pada mitra adalah peralatan produksi pencetak lakso dan pengering lakso masih manual. (sumber panas matahari). Permasalahan lain tentang pengelolaan penyediaan lakso, atau penjualan. Capaian yang dihasilkan, semakin terjalinnya kerjasama mitra UKM Produksi Lakso Pak Umar dengan Polmanbabel, wujud pelaksanaan Tri Dharma Perguruan Tinggi, yaitu terapan keilmuan mahasiswa dalam penyediaan mesin/alat Pengering lakso berkapasitas 4-5 kg (sistem rak tray rotary, bahan alumunium), dan sarana penelitian dan Pengabdian Masyarakat oleh Dosen dan/atau mahasiswa. Hasil kegiatan yang terlaksana, pemahaman dan penguasaan pengoperasian dan perawatan tentang produksi dari mesin yang disediakan. Ketercapaiannya persentase pengeringan lakso hingga $80 \%$ dan lakso mampu bertahan hingga 3 bulan. Penyajian lakso yang dikering dapat dilakukan dengan proses pengukusan.

Kata Kunci: Lakso, Pengeringan, Produksi, Pengelolaan Usaha

\section{PENDAHULUAN}

Propinsi Bangka Belitung dikelilingi oleh laut yang memiliki banyak jenis ikan yang bisa dimakan dan diolah menjadi makanan, dan memiliki kandungan energi yang sangat tinggi. Salah satu kuliner khas

Iptek bagi Masyarakat (ibM) Pemanfaatan Teknologi Tepat Guna pada Kelompok Masyarakat Pembuat Lakso di Kabupaten Bangka (Zulfan Yus Andi) 
Bangka Belitung adalah Lakso. Lakso merupakan salah satu jenis makanan penganti nasi karena terbuat dari tepung beras. Biasanya laksa bisa ditemui di warung-warung/kantin/toko/restaurant, acara-acara pernikahan, kenduri, dan hotel. Penyajian laksa ini biasanya disertai dengan kuah santan dengan suwiran daging ikan tenggiri dan ditaburi bumbu dan bawang goreng. Rasanya sangat nikmat dan mengiurkan.
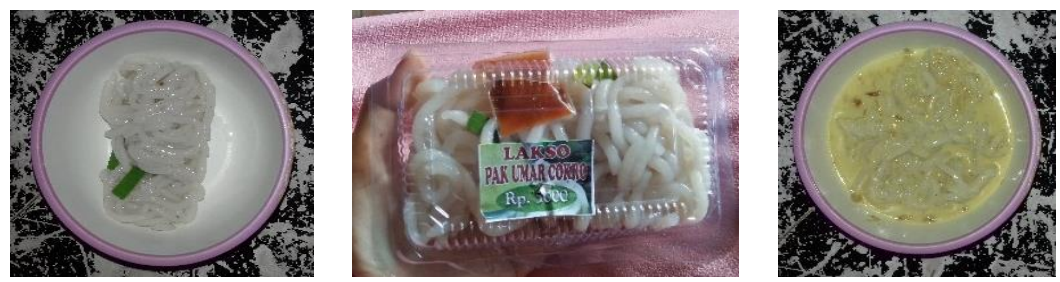

Gambar 1. Makanan Laksa

Lakso hanya bertahan 1 hari pada kondisi normal tetapi bisa bertahan 2-3 hari kalau posisinya di letakan di pendingin makanan. Maka dari itu lakso ini sulit di bawa kemana-mana sepeti Mie instan. Untuk saat ini belum ada sebuah alat pengering lakso yang otomatis agas lakso bisa dibawa keluar daerah dan menjadi buah tangan untuk propinsi Bangka belitung. Tujuan proses pengeringan adalah menurunkan kadar air bahan sehingga bahan menjadi lebih awet, mengecilkan kapasitas/volume bahan sehingga memudahkan dan menghemat biaya pengangkutan, pengemasan dan penyimpanan. Prinsip utama pengeringan adalah pengeluaran air dari bahan akibat proses pindah panas yang berhubungan dengan adanya perbedaan suhu.

\subsection{Analisis Situasi Mitra}

Mitra pelaksanaan IbM adalah kelompok usaha pembuat Lakso Ibu Yuli di Jalan Cokro Aminoto, RT.03, RW.02, Kabupaten Bangka. Usaha ini milik bapaknya yang telah ditekuni tahun 2002, dan usahanya berkembang tahun 2005. Pemasaran dengan proses berantai (natural/manual), perkenalan dari pelanggan satu ke pelanggan lain, pelanggannya mencakup wilayah Sungailiat, terkadang Pangkalpinang. Kelebihan lakso ibu Yuli tidak menggunakan pengawet. Pembuatan lakso dimulai pengolahan daing ikan, pembuatan adonan, pencetakan, pengukusan, penjemuran (untuk lakso kering), pengepakan, dan pemasaran.

Masalah utama produksi lakso, pengeringan lakso, selain manajemen kebutuhan lakso oleh konsumen, penjelasan Bab 1. Karena banyak permintaannya ketika kegiatan hajatan, lebaran, atau acara-acara pemerintah, sehingga membutuhkan tenaga extra untuk penyediaannya, maka sering terjadi penolakan pesanan karena kapasitas banyak. 5 bulan data terakhir, belum terpenuhi lakso \pm 75 $80 \%$ untuk lakso basah dan $1 \%$ untuk lakso kering perbulan, yaitu belum mencukupi permintaan Lakso di pasar yang membutuhkan minimal $250 \mathrm{~kg}$ perbulan.

\subsection{Permasalahan Mitra}

Hasil survey menunjukkan permasalahan mitra dihadapi persoalan proses pengeringan dan manajemen usaha (pemenuhan kapasitas pesanan). Pertimbangan pengeringan diantaranya waktu yang cepat, tanpa merubah warna, lakso tahan lama, dan cita rasa.

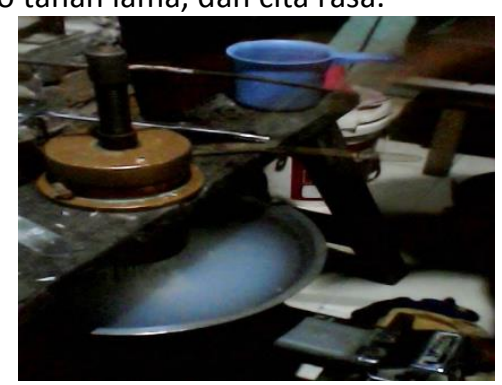

Gambar 2. Kondisi Mitra pada proses pembuatan lakso

Prosesnya yang dilakukan sekarang, sebagai berikut: Pengeringan manual (mengandalkan panas matahari, sehingga waktu lama), Kondisi cuaca mendung (pengeringan tidak dapat dilakukan), pengeringan waktu lama (laksa timbul jamur sebelum kering, mengakibatkan menjadi basi dan tidak layak konsumsi). 
Sedangkan pada persoalan manajemen usaha dapat dijelaskan, yaitu pemasaran secara mandiri, tidak memiliki sponsor (spanduk).

Laksa banyak dijual di toko-toko/warung/kantin, restaurant, acara-acara pernikahan, kenduri, dan pesanan hotel. Laksa dikemas dalam cup plastis kue dan harga 1 porsi lakso dijual dengan harga Rp.3000-Rp.5000. Pembuatannya tidak memerlukan keterampilan khusus karena siapapun bisa melakukannya.

\subsection{Makna Eksistensi Mitra di Lingkungan Masyarakat}

Usaha kecil dan menengah (IKM) Lakso Pak Umar banyak memberikan manfaat bagi masyarakat Sungailiat, diantaranya;

1. Pelestarian kuliner daerah

2. Membuka peluang masyarakat sebagai nilai tambah, jual beli lakso

3. Membuka dan menyerap tenaga kerja baru

Penyediaan mesin ini memberikan kontribusi UKM Pak Umar dan kesempatan masyarakat dalam pengembangan pasar produk lakso (kering), sekaligus promosi pengembangan pelestarian kuliner khas Bangka Belitung.

\subsection{Solusi dan Target Luaran Mitra}

Target dan luaran dari kegiatan IbM ini diharapkan dapat terjalin hubungan kerjasama yang saling menguntungkan antara mitra dengan tim $\mathrm{I}_{b} \mathrm{~m}$ dari Institusi Pendidikan. Mitra akan mendapatkan teknologi tepat guna berupa alat pengering laksa dan pelatihan menajemen usaha, sedangkan institusi dapat menerapkan iptek secara langsung dan menerapkan keilmuannya ke dalam teknologi tepat guna. Secara detail target luaran yang diharapkan dalam IbM, adalah;

1. Penyediaan Mesin 1 Unit, termasuk buku manual

2. Adanya proses pengeringan lakso

3. Keseragaman kapasitas/berat lakso

4. Peningkatan konsumen

5. Pengetahuan dan pemahaman pengoperasian dan perawatan mesin

\section{METODE PELAKSANAAN DAN HASIL YANG DICAPAI}

\subsection{Keterlaksanaan Kegiatan dalam Penyediaan Mesin}

Pelaksanaan kegiatan pengabdian ini, menindak lanjuti penyediaan mesin press lakso dari kegiatan pengabdian mandiri tahun 2016. Hasil IbM berupa mesin pengering yang komponan (parts) dibuat langsung dan komponen standar menggunakan part pasaran yang dibeli. Uraian system/subsystem kerja mesin yang di operasikan.

Komponen-komponen capaian dalam penyediaan mesin:

a. Pembuatan komponen dan perakitannya : (1) Cover \& Body Mesin, (8) Gagang Penutup, (9) Pengunci, (10) Kaca, (12) Kopling \& Dudukannya, (13) Rak \& Rangka landasan Lakso, (14) Rangka Mesin;

b. Pembelian komponen dan perakitannya : (2) House bearing, (3) Tabung gas, (4) Regulator, (5) Selang, (6) kompor gas, (7) Thermometer, (11) Motor
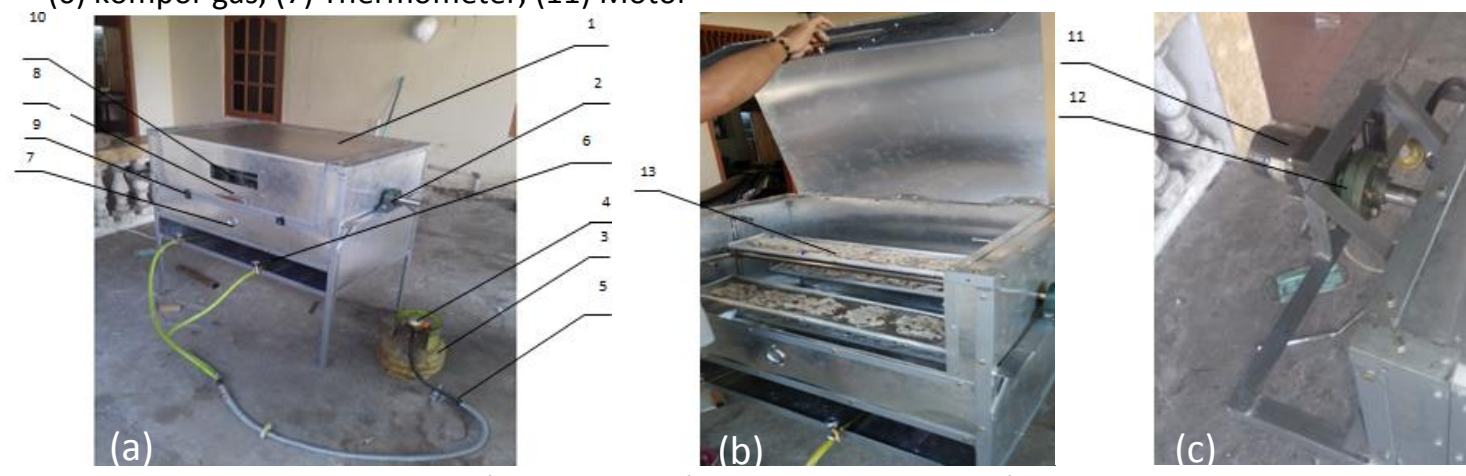

Gambar 3. Konstruksi Mesin Pengering Lakso

(a) Mesin Pengering (b) Rak penempatan media kering (c) Sumber Penggerak 


\subsection{Tahapan Penyediaan Mesin, Kegiatan dan Hasil Pelaksanaan PKM}

Untuk mengatasi atau menyelesaikan persoalan yang terjadi pada Mitra, langkah-langkah:

1. Pengumpulan Data Penyedia Mesin

Tim PKM mendatangi mitra usaha Lakso Pak Umar Jalan Cokro, melihat secara langsung proses pembuatan lakso hingga packing. Hasil pertemuan dalam diskusi, adalah:

- Mampu mengerinkan lakso dengan kemampuan hingga 1 bulan bertahan, atau mampu

mengeringkan lakso dari $100 \%$ ke $34 \%$

- Bentuk tetap, juga dapat mengeringkan lakso dengan warna tidak berubah

- Mudah dalam pengemasan, jika bentuk tetap sama

- Mudah dalam penyajian, yaitu direbus atau kukus

- Higenis

Selain melakukan survey, dilakukan pengumpulan data dari hasil tuntutan dan masukan dari beberapa orang Dosen; Aman dalam penggunaan mesin, Meminimalkan penggunaan daya listrik, Menghasilkan putaran dan suhu sama/stabil dalam proses pengeringan, dan Kapasitas $4 \mathrm{~kg}$

Selanjutnya Tim melakukan percobaan pengeringan metode lain, yang menggunakan peralatan seperti Timbangan, Oven, Pengukur Suhu, Lakso basah, yaitu experimen:

a. Pengeringan Menggunakan Oven rumah tangga yang umum digunakan

b. Pengeringan Menggunakan Matahari

Data pengujian tersebut, didapatkan beragam tingkat kekeringan, yaitu pengeringan lakso basah menggunakan Oven dibutuhkan waktu \pm 150 menit $( \pm 2.5$ jam), pengeringannya hingga $\pm 68 \%$, dan menggunakan matahari membutuhkan waktu \pm 8 jam dan pengeringan hingga $\pm 68 \%$.

2. Perancangan dan Penggambaran Konstruksi Mesin

Perancangan mesin mengikuti etika pembelajaran metode perancangan VDI 2222, seperti indikasi fungsi mesin, penentuan konsep system dan subsystem mesin, penentuan part-part/bagianbagian komponen mesin, perhitungan konstruksi mesin, estetika mesin, system kerja, dan kemampuan teknis pembuatannya, serta menghasilkan rancangan konstruksi pengering yang diharapkan (gambar 4 kiri).

3. Pembuatan dan Perakitan Mesin
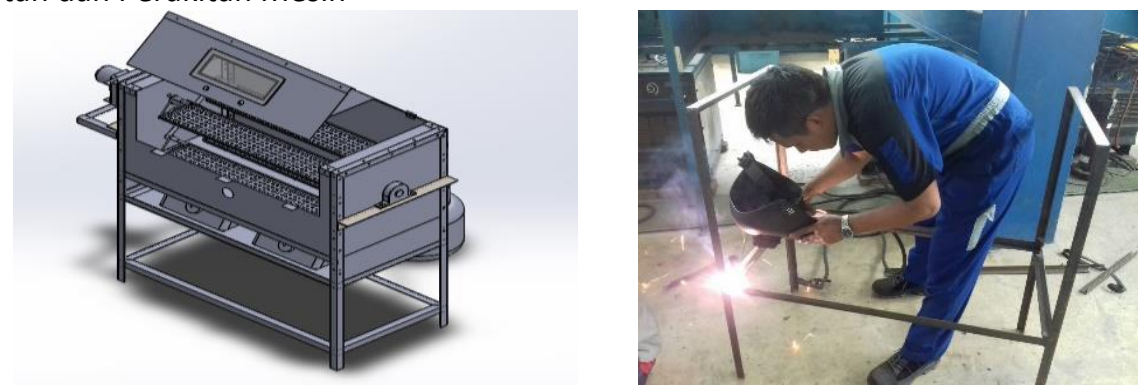

Gambar 4. Konsep Rancangan Mesin pengering lakso (kiri), Pembuatan Rangka Mesin (kanan)

Kemudian penyediaan part dan pembuatan part-part berdasar kebutuhan konstruksi mesin hasil draft. Secara teknis pembuatannya di Laboratorium Mekanik Polmanbabel, meliputi proses kerja bor, frais, gerinda, lasan \& pabrikasi, juga pengecatan. Setelah semua komponen yang dibuatkan/diproses pemesinan telah selesai dan terkumpulkan, termasuk komponen yang dibeli secara langsung telah tersedia. Selanjutnya dilakukan perakitan seluruh komponen tersebut hingga mesin akan siap diuji coba.
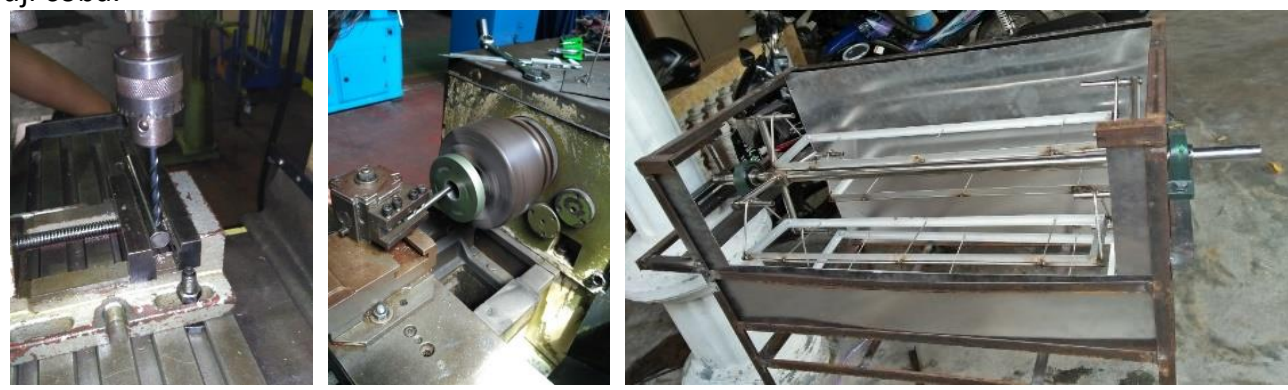

Gambar 5. Proses Pengeboran Poros Putar Rak Dudukan Lakso (kiri), Pembubutan Kopling Transmisi untuk Pemutaran Rak Pengering (tengah), Perakitan konstruksi (kanan) 


\section{Uji Coba Mesin dan Evaluasi}

Uji coba dilakukan dengan mengoperasikan mesin dengan dan/atau tanpa beban lakso, yaitu : mesin dihidupkan, dilakukan uji coba terhadap kerja mesin pengering lakso kapasitas masing-masing rak $1 \mathrm{~kg}$ (total $4 \mathrm{~kg}$ ) atau tanpa lakso, dimulai dari fungsi rangka, cover, penggerak \& transmisi, fungsi rak, pemanas (pengering lakso), dan indikasi suhu. Secara bertahap, Bagian/subbagian mesin dapat bekerja sesuai fungsi dan subfungsi masing system/subsystem.

Setelah dilakukan uji coba kemampuan teknis mesin, dilakukan uji coba kapasitas \& capaian pengeringan mesin. Sehingga data uji coba mesin pengering dapat dibandingkan dengan hasil proses pengeringan menggunakan oven dan menggunakan matahari.

Tabel 1. Hasil Pengeringan Lakso dengan 3 Metode Pengeringan

\begin{tabular}{lcccc}
\hline \multicolumn{1}{c}{ Metode Pengeringan } & Waktu & Hasil pengeringan & Warna Lakso & Ketahanan Lakso \\
\hline \hline Menggunakan mesin & \pm 5 jam & Berkurang $80 \%$ & Tidak berubah & Di atas 3 bulan \\
\hline Menggunakan oven & $\pm 2,5$ jam & Berkurang 68\% & Tidak berubah & Maks. 1 hari \\
\hline Menggunakan matahari & \pm 8 jam & Berkurang 68\% & Tidak berubah & Maks. 3 hari \\
\hline
\end{tabular}
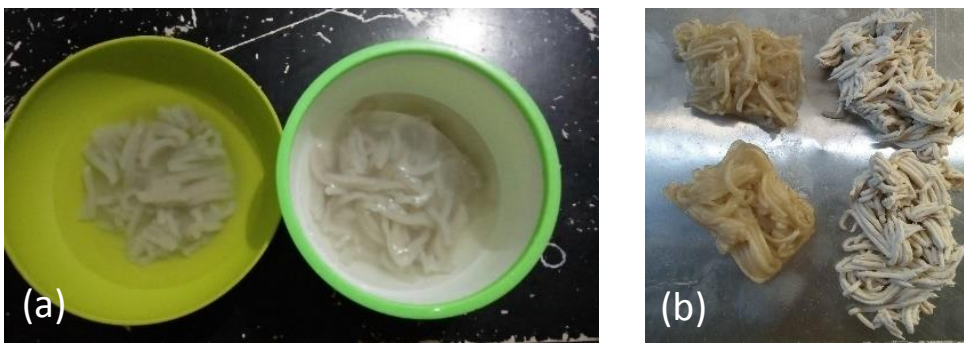

Gambar 6. (a) Lakso siap saji, tidak dikeringkan (kiri), sebelumnya dikeringkan (kanan)

(b) Tampilan lakso, Lakso kering (kiri), adonan lakso (kanan)

Hasil di atas, menunjukkan pengeringan lakso yang menggunakan mesin, menghasilkan lakso tahan lama. Sedangkan ke-3 metode ini juga tidak merubah warna lakso ketika dikeringkan, siap saji dari hasil pengeringan, pengukusan lebih disarankan darai pada perebusan lakso, karena perebusan melemahkan lakso. Konstruksi rak putar dan cover atau dinding mesin menggunakan bahan alumunium (gambar 3b), maka higenis lakso tetap terjaga, dan penggunakan motor putar (gambar 3c) di bawah 100 watt.

5. Pendampingan dan Monitoring Pemanfaatan Mesin dan Produksi

Selanjutnya serah terima mesin ke pengguna/mitra kerjasama, termasuk pelatihan pengoperasian mesin dan melakukan perawatan mesin, diarahkan menggunakan buku panduan mesin pengering (tercantum spesifikasi mesin, hal-hal yang dihindari dalam pengoperasian mesin, operosional mesin, dan perawatannya).
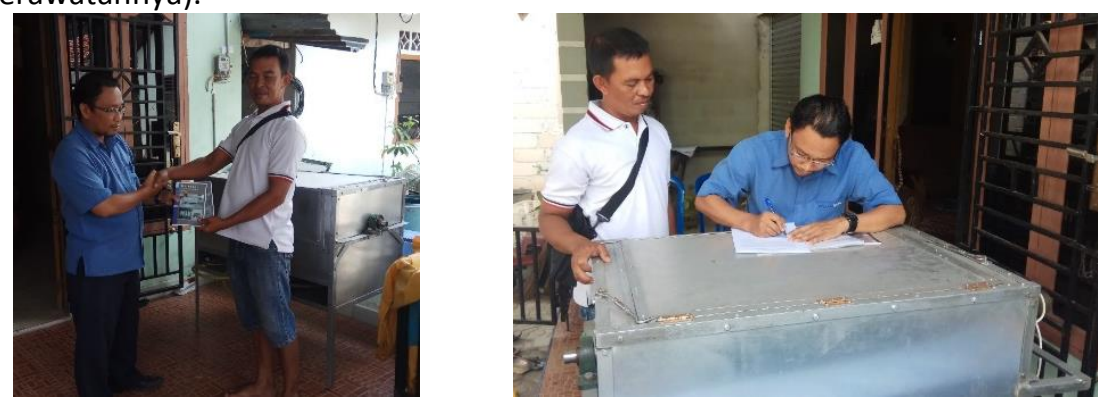

Gambar 7. Serah terima Mesin ke Mitra

Hal yang tidak kalah pentingnya dalam keterlaksanaan pemanfaatan mesin pengering lakso ini, yaitu monitoring dan evaluasi terhadap capaian dari hasil penyediaan peralatan/mesin pengering yang diberikan ke mitra. Berdasarkan hasil monitoring yang dilakukan (Bab 3), mesin pengering lakso dapat beroperasi dengan baik. Kapasitas produksi mesin belum terindikasi baik, karena belum terbiasanya penggunaan mesin tersebut. Akan tetapi Mitra tidak lagi mengalami kendala dalam 
memproduksi pengeringan lakso, karena saat ini sudah ada mesin sebagai alat bantu pengeringan yang tidak tergantung dari panasnya matahari.

\section{SIMPULAN}

Secara umum pelaksanaan PKM dimulai pada persiapan, penyediaan mesin, kegiatan pelatihan, monitoring kegiatan, dan pelaporan, sehingga dapat disimpulkan sebagai berikut;

a. Penyediaan mesin melibatkan kelompok mahasiswa tugas akhir, sebagai peningkatan akademik \& terapan keilmuan mahasiswa tersebut dalam menciptakan teknologi. Dan selanjutnya telah serah terima mesin, uji coba, pemakaian/pengoperasian, dan pelatihan-pelatihan produksi lakso.

b. Hasil pengeringa mesin lebih baik dibandngkan dengan pengeringan matahari, dan oven, yaitu lakso tahan lama, pengeringan hingga 80\%, waktu pengeringan \pm 5 jam/proses, daya listrik di bawah 100 watt, menggunakan sumber panas gas bakar (tidak tergantung musim alam), hiegenis (bahan alumunium), penamilan lakso hamper tidak berunah, \& proses selanjutnya hanya mengukus.

c. Akan tetapi perlu beberapa hal yang perlu diperhatikan untuk pengembangan berikurnya ;

- Identifikasi dan akumulasi biaya operasional \& nilai jual, diantaranya penggunaan gas, dan faktor resiko yang didapatkan;

- Layout penempatan lakso yang dapat memperbanyak pengeringan lakso;

- Kekedapn panas pada cover mesin, berikut metode transfer panas kompor ke media kering.

d. Telah dilakukan publish dan desiminasi mesin pengering lakso.

\section{UCAPAN TERIMA KASIH}

Ucapan terima kasih disampaikan kepada Institusi dan Bagian P3KM Polmanbabel yang telah memberikan dana hibah pengabdian masyarakat tahun 2017 dengan baik.

\section{DAFTAR PUSTAKA}

[1]. Harry Surya dkk, Teknik Kimia Pengeringan, Medan: Universitas Sumatra Utara, 2013.

[2]. Bella M.H., Asih F.R., Sri A.M., 2. Metode Pengeringan Rotary Dryer, Purwokerto: UNSOED, 2009.

[3]. Mujianto, "Analisis Faktor Yang Mempengaruhi Proses Produksi Tempe Produk UMKM di Kabupaten Sidoarjo", Jurnal Reka Agroindustri Media Teknologi dan Manajemen Agroindustri, Surabaya, vol.1, no.1, 2013.

[4]. Manajemen Usaha Kecil, Direktorat Pembinaan Kursus dan Kelembagaan, Direktorat Jenderal Pendidikan Non Formal dan Informal, Kementerian Pendidikan Nasional, 2010.

[5]. Dr. Halimatuddahliana, Jenis-jenis Alat Pengering, Medan: Departemen Teknik Kimia-USU, 2013.

[6]. Agungsupomo, Pengeringan, Lampung: Fakultas Pertanian, 2012. 